Editorial article / Редакционная статья

\title{
Identity in the Political Constructions of Modernity: Editorial Introduction
}

\author{
L.A. Fadeeva \\ Perm State University, Perm, Russian Federation
}

\begin{abstract}
L.A. Fadeeva is the author of numerous publications and key co-author of fundamental encyclopedias published by the Russian Academy of Sciences (Identity: The Individual, Society and Politics. An Encyclopedia, 2017) and the Russian Political Science Association (Trends and problems of the development of Russian political science in the global context: Tradition, reception and innovation, 2018), representing the leading scientific school for identity studies in Russia (see: Perm School of Political Science: Sources, Development, Content, 2019), who has served multiple times as guest editor for the thematic issues of the best Russian political science journals on this topic (Political science (RU), 2020, No. 4). In this introductory article, our guest editor L.A. Fadeeva presents the materials of the current issue of our journal, interpreting their cross-cutting themes as the politicization of the non-political through the prism of identity processes at the macro-regional, regional and national levels.
\end{abstract}

Keywords: identity, identity politics, political self-identification, multi-subject nature, post-Soviet space

For citation: Fadeeva, L.A. (2021). Identity in the political constructions of modernity: Editorial introduction. RUDN Journal of Political Science, 23(4), 521-524. DOI: 10.22363/2313-1438-202123-4-521-524

\section{Идентичность в политических конструкциях современности: представляю номер}

\author{
Л.А. Фадеева \\ Пермский государственный национальный исследовательский университет, Пермь, \\ Российская Федерация
}

\begin{abstract}
Аннотация. Во вводной статье приглашенный редактор Л.А.Фадеева, автор многочисленных публикаций и ключевой соавтор фундаментальных энциклопедий, издаваемых РАН («Идентичность: Личность, общество, политика: энциклопедическое издание», 2017) и РАПН («Тенденции и проблемы развития российской политической науки в мировом контексте: традиция, рецепция и новация», 2018), представляющая ведущую в России научную школу (см: «Пермская политологическая школа: истоки, становление, специфика», 2019) по исследованиям
\end{abstract}

(C) Fadeeva L.A., 2021

(c) () This work is licensed under a Creative Commons Attribution 4.0 International License https://creativecommons.org/licenses/by/4.0/ 
идентичности и не в первый раз выступающая приглашенным редактором тематических номеров лучших российских политологических журналов по этой тематике (журнал «Политическая наука», 2020, № 4) представляет материалы номера, трактуя их сквозную тематику как политизацию неполитического через призму идентитарных процессов на макрорегиональном, региональном и национальном уровне.

Ключевые слова: идентичность, политика идентичности, политическая самоидентификация, многосубъектность, постсоветское пространство

Для цитирования: Fadeeva L.A. Identity in the political constructions of modernity: Editorial introduction // Вестник Российского университета дружбы народов. Серия: Политология. 2021. T. 23. № 4. C. 521-524. DOI: 10.22363/2313-1438-2021-23-4-521-524

In the analysis of identity, the key problem is combining the macro and micro levels of research. As is the case for political science in general, it is important to identify how the politicization of the non-political occurs, and what influences this process. The multi-subject nature of identity politics is of particular interest, regardless of the interpretation of this concept. These problems are reflected in this issue of the journal.

The articles presented in this issue cover a wide range of problems and dimensions of identity. The research questions and dimensions of identity raised in them intersect, overlapping the geographical framework of the three blocks they are divided into: the Identity of Russia, the Identity of Post-Soviet Countries and the Identity of Europe.

The first article by leading professors of St. Petersburg and Moscow State Universities Vladimir Gutorov and Alexander Shirinyants analyzes the postcommunist transformations of the post-Soviet space through rethinking Marxist approaches. It provides a historical perspective on the conversation about identity and the variety of research optics that can be used to approach this topic.

Higher School of Economics professor Yuliy Nisnevich suggests considering the post-Soviet transformation in Russia to analyze the dramatic disengagement of the democratic movement from the new ruling stratum - the Russian nomenclature.

The crisis of traditional parties and the search for new political trends and brands are characterized in an article by Denis Dumler, a young scholar from Perm State University, dedicated to the political self-identification of Russian libertarians in a comparative perspective and the reasons for their popularity among young people.

The political sentiments of young people are the focus of our constant attention. In this issue, Aleksandr Shchekoturov, the Head of the Sociological Laboratory of the Institute for Geopolitical and Regional Studies, Immanuel Kant Baltic Federal University, offers a political and sociological analysis of the values of loyal and oppositional youth in the Kaliningrad region. His colleague Mikhail Krishtal reveals the relationship between the ideological attitudes of the region's residents of all ages and their political behavior.

The confessional dimension of identity politics is attracting increased attention from the scientific community. Natalya Shikher, a postgraduate student at the 
Russian Presidential Academy of National Economy and Public Administration, and the Head of the Department of the Office of the Commissioner for Human Rights in the Russian Federation, characterizes the political dimension of Orthodox identity in the context of how the activities of the World Russian People's Council impact state policies in the field of the freedom of conscience in modern Russia.

The guest editor of this issue Lyubov Fadeeva and Dmitrij Plotnikov from Perm State University discuss the classical understanding of identity politics, analyzing the algorithms of identity politics in the European countries of the post-Soviet space. The authors describe the aggravating confrontation between the countries of the region over the choice of the European vector of identity politics along the West/Russia axis.

The topic of the competition between states in the space of values and the value expansion of the EU among the European post-Soviet countries is continued in the article by Natalia Pankevich, an associate professor at the Institute of Philosophy and Law, Ural Branch of the Russian Academy of Sciences, who defines the institutional mechanisms of the value expansion of the EU and the possibilities of protective strategies.

RUDN University professor Maria Mchedlova and Russian-Armenian (Slavonic) University professor Hovhannes Sargsyan, talk about civic identity through the prism of project and protest identity in research, conducted within a joint scientific project on civic identity in the post-Soviet space.

When studying identity problems in European countries, the case of the former Yugoslavia is of particular interest to Russian readers. The parallels between the post-Soviet and post-Yugoslavian space are obvious, which opens up a broad perspective for comparative analysis.

Ilya Pomiguev (HSE University, ISISS of Russian Academy of Sciences, Financial University under the Government of the Russian Federation) and Eldar Salakhetdinov (Institute for African Studies of the Russian Academy of Sciences, University of South Africa) consider one of the directions of identity politics - the politics of memory in Yugoslavia and post-Yugoslav states, in a historical perspective.

Aleksandar Djokic, a young scholar from RUDN University, together with his colleague Guillaume Pichelin from the Bordeaux Institute of Political Studies, based on their qualitative and quantitative research, explain not only the inability to build a common Yugoslav civic identity but also the impact of this failure on the relationship between Serbian and Croatian civil societies, defining the prospects for reconciliation and civic identity building in Serbia and Croatia.

Identity politics, as a political course focused on protecting the rights of oppressed (deprived) minorities, activates right-wing politics throughout the world. HSE University postgraduate student Ivan Petrov, comparing the databases of rightwing parties in Europe, reveals serious differences in the structure of the party spectrum in, on the one hand, Northwest and, on the other hand, Central and Eastern European countries. The researcher challenges the traditional identification of the 
ultra-right, which does not take into account the regional differences and the factor of spatial competition.

The transformation of the party identity of German right-wing radicals is analyzed in an article by Ekaterina Burmistrova, a lecturer of the Perm State University, who characterizes the attempts of the right-wing in Germany at demarginalizing by addressing human rights issues and protecting European identity.

Received / Поступила в редакцию: 14.08.2021 Accepted / Принята к публикации: 15.08.2021

\title{
References / Библиографический список
}

Fadeeva, L.A. (2018). Political identity. In O.V. Gaman-Golutvina \& S.V. Patrushev (Eds.), Trends and problems of the development of Russian political science in the global context: Tradition, reception and innovation (pp. 431-445). Moscow: Political encyclopedia. (In Russian).

Фадеева Л.А. Политическая идентичность // Тенденции и проблемы развития российской политической науки в мировом контексте: традиция, рецепция и новация / отв. ред. О.В. Гаман-Голутвина, С.В. Патрушев. М.: Политическая энциклопедия, 2018. C. 431-445.

Fadeeva, L.A. (2019). Perm School of Political Science: Sources, Development, Content. Political Expertise: Politex, 15(1), 122-138. https://doi.org/10.21638/11701/spbu23.2019.109 (In Russian).

Фадеева Л.А. Пермская политологическая школа: истоки, становление, специфика // Политическая экспертиза: ПОЛИТЭКС. 2019. Т. 15. № 1. С. 122-138. https://doi.org/ $10.21638 / 11701 /$ spbu23.2019.109

Fadeeva, L.A. (2020). Introducing the issue. Political science (RU), 4, 9-12. (In Russian). Фадеева Л.А. Представляю номер // Политическая наука. 2020. № 4. С. 9-12.

Identity: The Individual, Society and Politics. An Encycpopedia. (2017). I. Semenenko (Ed.). Moscow, Ves Mir. (In Russian).

Идентичность: Личность, общество, политика. Энциклопедическое издание / отв. ред. И.С. Семененко. М.: Издательство «Весь Мир», 2017.

\begin{abstract}
About the author:
Lyubov A. Fadeeva - Doctor of Historical Science; Professor, Political Science Department, Perm State University; Chief Editor, "Bulletin of Perm University. Political Science"; Editorial Board Member, "World Economy and International Relations", "South-Russian Journal of Social Sciences"; Member of the Scientific Council and the Board of the Russian Political Science Association (e-mail: polsci@yandex.ru) (ORCID ID: 0000-0002-3389-750X)
\end{abstract}

\section{Сведения об авторе:}

Фадеева Любовь Александровна - доктор исторических наук, профессор кафедры политических наук Пермского государственного научно-исследовательского университета (e-mail: polsci@yandex.ru) (ORCID ID: 0000-0002-3389-750X) 